to keep in touch with them after they go back. He thought that it would be a good thing if universities were to endeavour to establish contact with men engaged in industrial and administrative work in the outlying parts of the Empire. Sir Theodore Morison thought the Colonial Office should remodel its antiquated system of recruiting for scientific services.

The discussion of the fourth subject, the interchange of university teachers and students, was opened by Sir Henry Miers. A mode of exchange which has recently been tried with success by Cambridge and Manchester is as follows : a professor of university A obtains leave to spend a term at university $\mathrm{B}$, where he is received on the footing of supernumerary professor and obtains a thorough insight into the working of the department without undertaking responsibility for its administration. Afterwards a return visit is paid by a professor of the same department of university $\mathrm{B}$ to university $\mathrm{A}$. Inter-university visits of junior teachers and graduate students have been successfully arranged, and nothing but the cost of crossing the Atlantic prevents the development of a very extensive interchange of such visits between Great Britain and America. It is desirable from an imperial and international point of view that interchange, especially of young teachers, both between the home universities and those in other parts of the Empire and between British and foreign universities, should be systematically encouraged, as it is by governments or associations in other countries. Sir Richard Lodge praised, in this connexion, the work of the Student Christian Movement. Dr. Hickson of Manchester thought it important also to encourage interchange of teachers between the home universities. Dr. Duniway, of the American University Union, remarked that American universities are eager to provide facilities in the form of part-time employment for visits by young British university teachers and other graduates, and that the administrators of American universities look upon the whole civilised world as their recruiting ground for their summer school staff. Two visitors from Australian universities recommended that steamship companies be approached with the view of obtaining concessions for graduates visiting Australian universities from Great Britain similar to those already in force for visits in the opposite direction.

A full report of the proceedings is in preparation and will be issued from the Universities Bureau of the British Empire, 5o Russell Square, W.C.I.

\title{
The Sir William Dunn Institute of Biochemistry, Cambridge.
}

$\mathrm{O}^{\mathrm{N}}$ Friday, May 9, the recently completed Sir William Dunn laboratories in which the Cambridge School of Biochemistry is now housed were officially opened by the Earl of Balfour, Chancellor of the University. Upwards of 400 guests, a gathering representative of all faculties of the University of Cambridge and of many outside academic and public bodies, were present when the Chancellor rose to call upon Sir Jeremiah Coleman, the chairman of the board of trustees of the late Sir William Dunn, to make his statement.

Sir Jeremiah Coleman explained the circumstances in which the trustees had allocated the money which Sir William Dunn had desired should be devoted to the alleviation of human suffering, to found this great institute in Cambridge, in the opinion that this was the most fruitful way in which the testator's wishes could be carried out. For the erection of the building and its endowment the sum of $210,000 l$. had been given. (In addition, Sir Jeremiah himself has made a generous private gift toward the endowment of the library of the School.)

The trustees' formal statement having been read by Sir Jeremiah Coleman and the building thus handed over to the University, the Chancellor gave his address. After thanking Sir Jeremiah and the board of trustees as the discerning agents of this great bequest, he recalled the earlier benefactions by which the beginnings of biochemistry in Cambridge had been made possible, and without which the present munificent gift could never have been made. The great object towards which the testator had desired that his estate should be applied could not have been better approached than in the direction which the body of trustees had chosen, that of the foundation of a great institute of research and teaching which should deal with the fundamental problems at the meeting-place of chemical and biological science, with the solution of which the well-being of the race, both now and in the future, was so intimately bound up. He instanced cancer, the scourge which had for many years defied the utmost clinical efforts, as being one of the urgent fields of work which might well yield up its secrets, to the immense benefit of humanity, in such a laboratory. The new foundation was particularly happy in having the genius of Prof. Gowland Hopkins to inspire and direct the endeavours of the devoted band of workers that was now gathered under his leadership.

The building was then declared open, and the guests were invited to visit the numerous demonstrations which had been arranged in the laboratory, illustrating the principal lines of research work which are being carried out at present in the School.

A three-storey edifice of dark red brick, the building was designed by Sir Edwin Cooper and built by Messrs. William Saint and Co., of Cambridge. It stands on land which was bought by the University from Downing College, has a frontage on Tennis-court Road, and overlooks part of the grounds of Pembroke College. Facing as it does somewhat south of west, every room in the building has the advantage of at least a portion of the day's sunlight. Behind, it shares with the School of Agriculture two sides of what will eventually become the second court of the group of natural science laboratories on the south side of Downing Street.

The library, the nucleus of which was built up in the vestry whilst the School of Biochemistry pursued its adolescent life in what had previously been a Dissenting Chapel, is now lodged, in the new building, in the more congenial oak of the southern groundfloor room, which contains four wood-carvings in relief, of Mayow, Liebig, Graham, and Pasteur. The library crosses the building from east to west, and is balanced by a lecture-room of similar dimensions at the northern end of the building, in which room may be found the earliest chemical lecture-room bench to be used in Cambridge, presented to the School by St. John's College. The offices and cloak-rooms are on this floor, together with six research and lecturers' rooms and another room where a not unimportant part of the day's routine is carried out from 4 to 4.30 P.M. On the first floor are Prof. Hopkins's private room and laboratory, another large room specially designed for bacteriological research, and eight research rooms. The second floor is taken up by one large laboratory for elementary, and a smaller one for advanced students, together with the necessary preparation rooms, and a lecturer's room. The basement contains service and store rooms, the workshop, engine-room, animal houses, and two research laboratories. 
Although originally designed to hold what appeared to be the ample number of 20 to 24 research workers, the laboratory has already a population of no fewer than 38 , of whom $\mathrm{II}$ are women. Included among these 38 are six members of the University staff, three Australians, a Canadian, a New Zealander, a citizen of the Irish Free State, an Indian, a Norwegian, and an American; whilst among the fellowships and exhibitions held are four Beit Memorial Fellowships for medical research, one Sir William Ramsay Memorial Fellowship, and two $185 \mathrm{r}$ Exhibitions.

The following list of problems, among those with which this body of workers is engaged, indicates the extremely wide field with which modern biochemistry is dealing : cell oxidations both in the animal and the plant; the mechanism of the action of glutathione and other oxidising enzymes; the properties and mode of action of insulin and other hormones; bacterial metabolism; protective syntheses in the animal ; inorganic metabolism; the constitution of casein, hæmatin, thyroxin; inositol metabolism; the rôle of phosphorus compounds in metabolism; vitamins; cancer; analytical methods; the colours of flowers ; the pigments of insects ; the optically active substances in blood.

Unless the promise of "Back to Methuselah" is fulfilled in this or some similar laboratory in the reasonably near future, the writer of these lines fears that he will not be able to be present at a ceremony which he would attend with the very greatest interest, namely, that of the centenary of the opening of the Sir William Dunn Institute of Biochemistry, when the magnificent possibilities of the 1.ew laboratories shall be in no small measure realised.

\section{Problems of Muscular Receptivity.}

SIR CHARLES SHERRINGTON, whose book $S$ "The Integrative Action of the Central Nervous System " has received world-wide attention, gave the Linacre Lecture in the Lecture Room of Anatomy and Physiology at Cambridge on May 6 . He commenced by pointing out that Linacre (the founder of the Royal College of Physicians), who is claimed first by the Grammarians as one of themselves, also initiated medical teaching on the banks of the Cam and the Isis. Linacre was a researcher in science at a time when scientific research was practically in its infancy. It is therefore very fitting that the lectureship which he founded should be devoted to a consideration of the results of research in medicine.

The reactions of the central nervous system involve two kinds of receptors, those of the special sense organs and those of the proprioceptive organs. The former arouse conscious reaction : the latter seldom do. On the other hand, the latter initiate complex reflex actions: the former do not do so often, except with the intervention of consciousness.

The muscles which form the motor mechanisms of the body, whether it be to fell a forest or pronounce a syllable, are called into action not only by reflexes, but also by the initiation of the will directly or indirectly dependent on the receptors above mentioned. But these muscles themselves are known to possess receptors which respond to events taking place not only outside but also within themselves, thus the term used for such receptive organs found in musclesthe "proprioceptor organs."

For the experimental investigation of such proprioceptors the still surviving body of the recently killed animal has to be used. It lies motionless or stands motionless unless stimulated; it can initiate no movements since the cerebral hemispheres are destroyed. The muscles preserve their tonus, which may be better called " postural contraction." To preserve this tone, the receptors somewhere must be reacting to stimuli, since the tone disappears when the nerves connecting all the receptors with the central nervous system are cut. Among these receptors are the pads of the soles of the feet and the skin of the limbs. Experiment shows, however, that these take little or no part. The principal part is played by proprioceptors in the animal's own muscles-those which hold up the head, those which keep the jaw closed, and those which keep it in the erect position against the action of gravity.

Experiment shows that a muscle, such as the knee extensor, which is about $100 \mathrm{~mm}$. long, will with nerves intact exert some 2 kilograms tension when stretched to IOI mmi. With nerves cut, no such tension is exerted. The intact muscle will, moreover, preserve the contraction even if it be allowed to return to its previous length of $100 \mathrm{~mm}$. If by means of appropriate electric stimulation we abolish the contraction, we find practically none of it was due to the passive stretching of the structure of the muscles. To this tension set up in a muscle as the result of stretching it the term "the stretch reflex" may be given.

Returning now to the whole animal and applying these experimental results, we find the active posture of standing is the summation of a large, highly organised number of stretch reflexes. Moreover, we observe a high degree of adaptability on the part of the animal. The feet may be planted in various positions and still the posture of standing is preserved.

Sir Charles explained in detail how this adaptability was brought about. He then enumerated the parts of the problem which have yet to be solved by further research, and concluded his lecture by saying that one of his hopes was that, as a result of the Linacre Lecture which he was delivering, more recruits would join the ranks of physiologists for the purpose of attacking some of these problems.

\section{University and Educational Intelligence.}

Durham. - Dr. A. K. MacBeth, lecturer in chemistry at the University of St. Andrews, has been appointed reader in chemistry in the Durham Colleges. Mr. H. J. E. Dobson, of University College, London, has been appointed lecturer in chemistry.

LEens.-Applications are invited for the open fellowship of $200 l$. per annum established by the Institution of Gas Engineers for the prosecution of post-graduate research in gas chemistry. The latest date for the receipt of applications by the Registrar of the University is June 2.

London.-Miss M. Tildesley, Research Assistant, Royal College of Surgeons, will deliver a free public lecture at University College (Department of Applied Statistics and Eugenics) on Tuesday, May 20, on Sir Thomas Browne, author of "Religio Medici" His Skull and Portraits. A free public lecture (in English) will be delivered at 5.I5 on Wednesday, May 2I, in the physics lecture theatre of the Imperial College, Royal College of Science, by Prof. P. Zeeman, on "The Optical Effects of Motion." "No tickets will be required for either lecture.

Applications are invited for the university studentship in physiology, value $50 l$. It will be awarded to a student qualified to undertake research in physio logy. The latest date for the receipt of applications is May 31. They should be sent to the Academic Registrar, University of London, South Kensington, S.W.7.

NO. 2846 , VOL. I I 3$]$ 